\title{
LITERATURE REVIEW Women users of crack: systematic review of Brazilian literature
}

\author{
Mulheres usuárias de crack: revisão sistemática da literatura brasileira \\ Jéssica Limberger', Raísa da Silva do Nascimento² ${ }^{2}$ Jaluza Aimèe Schneider', "llana Andretta ${ }^{3}$
}

\section{Keywords}

Crack cocaine, women, substance-related

disorders, drug use review.

\section{Palavras-chave}

Crack cocaína, mulheres, transtornos relacionados ao uso de substância, revisão sobre drogas.

\begin{abstract}
Objective: To present Brazilian's empirical studies that address this issue between the period of 2004 to 2014. Methods: It is a Brazilian literature Systematic Review using the descriptors "crack cocaine" AND "women", in the database Scopus, Lilacs, Medline and SciELO. Results: From the 785 articles found, 16 articles contemplated the inclusion criteria. It was evidenced that the use of crack by women is related to physical and sexual violence, provoking HIV risks in consequence of prostitution, and social prejudice. Conclusion: Given this reality, studies evaluating treatments in the Brazilian context are essential, according the specificities of women crack users.
\end{abstract}

\section{RESUMO}

Objetivo: Apresentar os estudos empíricos brasileiros que abordem o uso de crack em muIheres, no período de 2004 a 2014. Métodos: Trata-se de uma revisão sistemática da literatura nacional, utilizando os descritores "crack cocaine" AND "women", nas bases de dados Scopus, Lilacs, Medline e SciELO. Resultados: Dos 785 artigos encontrados, 16 artigos contemplaram os critérios de inclusão. Evidenciou-se que o uso de crack em mulheres está relacionado à violência física e sexual, além do HIV advindo da prostituição, bem como o preconceito social. Conclusão: Diante dessa realidade, estudos que avaliem tratamentos no contexto brasileiro são imprescindíveis, de acordo com as especificidades das mulheres usuárias de crack.

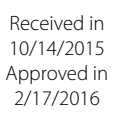

Approved in
$2 / 17 / 2016$
1 Universidade do Vale do Rio dos Sinos (Unisinos), Psicologia Clínica. 2 Pontifícia Universidade Católica do Rio Grande do Sul (PUCRS), Psicologia.

3 Unisinos, Programa de Pós-Graduação em Psicologia Clínica.

Address for correspondence: Ilana Andretta Universidade do Vale do Rio dos Sinos Av. Unisinos, 950, Bairro Cristo Rei Escola de Saúde, Programa de Pós-graduação em Psicologia 93020-000 - São Leopoldo, RS, Brasil iandretta@unisinos.br 


\section{INTRODUCTION}

Mankind makes use of psychoactive substances for over ten thousand years. However, only in the last two centuries there is a concern with the control of these substances in the production, distribution and use'. All over the world, there are challenges in the drug control system, in the violence that comes from drug trafficking and in the quick evolution of new psychoactive substances ${ }^{2}$.

The drug is seen as one of the factors in a triad of that leads to dependence, being the individual and the society the other two factors ${ }^{3}$. Therefore the disorder cause by the use of substance occurs not only in a neurobiological level, but also through structuring social bonds and behaviors turned to the consumption, pressing the individual for continued use, in detriments caused by other fields of life ${ }^{4}$.

In Brazil, the use of crack is established as a public health problem, being the largest crack market and the second largest cocaine market in the world, accounting for $20 \%$ of the world consumption ${ }^{5}$. The crack derives from cocaine and is a central nervous system's stimulant, increasing the neuronal activities, generating exaggerated alertness, insomnia and acceleration of psychic processes ${ }^{6}$.

The abuse of crack is more prevalent between men (78.7\%). However, the intensive use is higher by the women. In a day of increased consumption, women reported the consume of 21 crack rocks, while men report the consume of 13 rocks in the same period of time ${ }^{7}$. Profile data of crack users and/or similar in Brazil demonstrate specific features in female audience. For instance, 29.9\% of crack's dependent women already used the prostitution to get drugs. This proportion is $1.3 \%$ among men. In addition, more than half of the users got pregnant at least once since the beginning of use of crack/similar, setting risks during pregnancy, as neurological and intellectual development of the exposed children?

Studies have evidenced difficulties in maintaining abstinence during pregnancy, resulting in risks to the newborn, such as prematurity and congenital syphilis8. Traumatic stressful events are also indicated by most of the women, especially regarding physical aggression. In a study of women crack users, $44.5 \%$ of participants reported having experienced sexual violence in their lifetimes, compared to $7 \%$ in male users ${ }^{9}$.

It's noticed the vulnerability of women users of drugs, which require a different view from health professionals to ensure that specific features are prioritized, such as health promotion, self-esteem and social reintegration ${ }^{10}$. Thus, treatments for women have been indicated in international studies. A systematic review of international literature investigated the need for treatment programs for women crack users with legal problems ${ }^{11}$. Studies published between 2006 and 2009 were analyzed. The results disclose that the most effective treatment options have been focused on the women specificities and the inclusion of motivational strategies in treatment protocols ${ }^{11}$.

The lack of specific clinical approaches to women is due to the fact that, for a long time, the emphasis of studies with drug users was directed to male population ${ }^{9}$ and studies directed to women users of crack are still rare in the Brazilian literature ${ }^{12}$. Therefore, this study aims to describe how the use of crack by women has been investigated in Brazilian empirical studies, systematizing the findings and indicating gaps in the understanding of this phenomenon.

\section{METHODS}

It consists of a systematic review of Brazilian empirical articles on the use of crack by women. According to Zoltowski et al. ${ }^{13}$ the systematic review is a robust technique for evaluation and synthesis of literature, applied in different fields of knowledge.

The searches were conducted by two authors, independently and blindly in October 2014 through the databases Scopus, Lilacs, Medline e SciELO. The descriptors "crack cocaine" AND "women" were used in the fields: title, synopsis and subject. Such terms constitute the system of Descritores em Ciências da Saúde (DeCs). The following inclusion criteria was used: a) publications between 2004 and 2014; b) Brazil as the affiliation country of the authors. Exclusion criteria were: a) articles without the full text available; b) articles that do not address the use of crack by women; c) theoretical articles and literature reviews, comments, editorials or letters; d) articles that do not concern Brazilian reality on the use of crack by women and e) repeated articles. According to the article purpose, it was decided to exclude the published thesis pertaining to the subject in order to prioritize arising journal articles indexed in reliable databases.

\section{RESULTS}

The initial search resulted in 785 articles, which were selected based on inclusion and exclusion criteria, as the following flowchart (Figure 1).

From the 16 articles, $75 \%(n=12)$ were published in English and 25\% $(n=4)$ in Portuguese. Most of the articles, $81,25 \%$ ( $n=13$ ), were attended only by women and only 3 articles were with both genders. The year of 2013 had the highest number of publications ( $n=5$ ), followed by 2014 $(n=4)$ and $2012(n=3)$. The years with the lowest number of publications were $2008(n=2), 2011(n=1)$ and $2004(n=1)$. The following table presents the main characteristics of the selected articles (Table 1). 


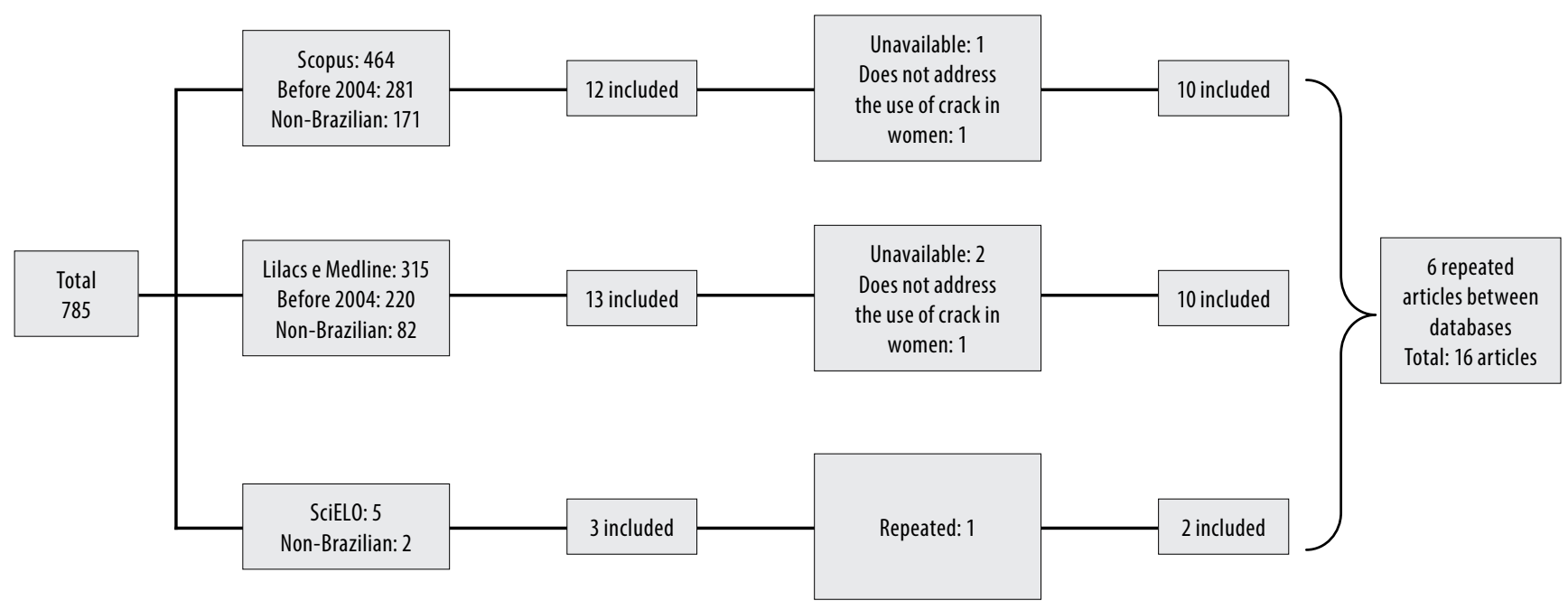

Figure 1. Flowchart of the identification and selection of publications.

Table 1. Study characteristics and results

\begin{tabular}{|c|c|c|}
\hline Authors and year & Delineation and instruments related to drug use & Participants \\
\hline Orsi et al. $(2004)^{15}$ & $\begin{array}{l}\text { Quantitative study, cross-sectional study. } \\
\text { Structured interview, questionnaire about } \\
\text { the use of cocaine and Cocaine Addiction } \\
\text { Scale. }\end{array}$ & $\begin{array}{l}74 \text { subjects of both sexes interned } \\
\text { in specialized treatment for cocaine } \\
\text { dependence in Porto Alegre/RS. }\end{array}$ \\
\hline Correa et al. $(2008)^{17}$ & $\begin{array}{l}\text { Quantitative study of epidemiological, } \\
\text { descriptive and analytical character. } \\
\text { Structured questionnaire. }\end{array}$ & $\begin{array}{l}75 \text { female sex workers in bars and } \\
\text { nightclubs, the city of Umuarama/PR. }\end{array}$ \\
\hline Malta et al. $(2008)^{18}$ & $\begin{array}{l}\text { Qualitative study, grounded theory. } \\
\text { Focus groups and in-depth interviews } \\
\text { were conducted. }\end{array}$ & $\begin{array}{l}26 \text { female sex workers crack users in Foz } \\
\text { do Iguaçu/PR. }\end{array}$ \\
\hline Nappo $(2011)^{19}$ & $\begin{array}{l}\text { Qualitative study. } \\
\text { Interviews. }\end{array}$ & $\begin{array}{l}75 \text { women dependent of crack, in São } \\
\text { Paulo/SP. }\end{array}$ \\
\hline Tractenberg et al. $(2013)^{24}$ & $\begin{array}{l}\text { Quantitative study. } \\
\text { SCID-I (Structured Clinical Interview for } \\
\text { DSM Disorders) ASI-6. }\end{array}$ & $\begin{array}{l}99 \text { women, aged between } 18 \text { and } 52 \\
\text { years admitted to a detoxification unit of } \\
\text { Porto Alegre/RS. }\end{array}$ \\
\hline Costa et al. $(2012)^{20}$ & $\begin{array}{l}\text { Quantitative, retrospective and } \\
\text { cross-sectional study. Semi-structured } \\
\text { interview. }\end{array}$ & $\begin{array}{l}85 \text { pregnant women dependent of } \\
\text { crack admitted for detoxification in } \\
\text { a psychiatric inpatient unit in Porto } \\
\text { Alegre/RS. }\end{array}$ \\
\hline $\begin{array}{l}\text { Grassi-Oliveira et al. } \\
(2012)^{28}\end{array}$ & $\begin{array}{l}\text { Quantitative study. } \\
\text { Socio-Demographic Data SCID I and } \\
\text { Addiction Severity Scale. }\end{array}$ & 23 women crack users in treatment. \\
\hline Levandowski et al. (2013) & $\begin{array}{l}\text { Quantitative study. } \\
\text { SCID I. }\end{array}$ & $\begin{array}{l}104 \text { women crack/cocaine users, } \\
\text { with and without a history of child } \\
\text { abuse in hospital treatment unit for } \\
\text { detoxification. }\end{array}$ \\
\hline Viola et al. $(2013)^{25}$ & $\begin{array}{l}\text { Cross-sectional and comparative Study. } \\
\text { Cocaine Selective Severity Assessment } \\
\text { and ASI-6. }\end{array}$ & $\begin{array}{l}85 \text { women crack/cocaine users, divided } \\
\text { in two groups: with a history of physical } \\
\text { neglect in childhood ( } \mathrm{n}=37) \text { with no } \\
\text { history of physical neglect in childhood } \\
(\mathrm{n}=48) \text {. }\end{array}$ \\
\hline
\end{tabular}

Throughout life, $55.4 \%$ of participants reported using crack. Among participants who used cocaine for longer, in its various forms, $87 \%$ were men and $12.8 \%$ were women. However, $80 \%$ of that used in larger quantities were women.

Most sex workers (67.0\%) were users of licit and illicit drugs, with higher consumption of tobacco (36.0\%). Associations between STDs and the use of legal and illegal drugs were found.

Drug use is seen by participants as a way to deal with stressful situations, as experiences of physical and sexual violence. Risk factors for HIV, such as multiple partners and unprotected sex were identified by participants.

Prostitution was identified as a way of obtaining the crack. The population was identified as a risk group in the transmission of sexually transmitted diseases such as AIDS.

The results indicate an exposure rate of $86.9 \%$ among trauma dependent women of crack cocaine type. The PTSD rate was $15.1 \%$. Among the types of reported events, the most frequent were: suffer aggression or physical abuse and be witness of violence.

The beginning of crack use varied between 11 and 35 years. Most of the women had involvement with robbery, prison, exchange of sex for money/drugs, home abandonment and HIV.

The study identified the association between cortisol levels (from the hair evaluation) and stress exposure by 90 and 30 days before starting treatment.

All users increased plasma levels of leptin during the abstinence period. However, the concentrations were lower compared with the group of non-users. The crack users who report childhood maltreatment showed a significant reduction in plasma levels of adiponectin and resistin compared to the group with no history of abuse.

Women crack/cocaine users with a history of physical neglect in childhood had lower performance on tasks of executive function when compared to women with no history of physical neglect in childhood. 


\begin{tabular}{|c|c|c|c|}
\hline Authors and year & Delineation and instruments related to drug use & Participants & Main results \\
\hline Francke et al. $(2013)^{23}$ & $\begin{array}{l}\text { Comparative quantitative study, with } \\
\text { follow-up. } \\
\text { SCID I. }\end{array}$ & $\begin{array}{l}80 \text { women treated in specialized unit for } \\
\text { chemical dependence. }\end{array}$ & $\begin{array}{l}\text { The results show a correlation between women who have suffered } \\
\text { neglect in childhood and with the lowest results in successful } \\
\text { treatment for drug addiction. }\end{array}$ \\
\hline $\begin{array}{l}\text { Diehl, Silva e Laranjeira } \\
(2013)^{31}\end{array}$ & $\begin{array}{l}\text { Quantitative study of cross-cutting } \\
\text { nature. } \\
\text { Questionnaire with the diagnosis criteria } \\
\text { of the DSM-IV-TR. }\end{array}$ & $\begin{array}{l}105 \text { women admitted to a specialized } \\
\text { unit of treatment for disorders related } \\
\text { to substance use in a tertiary psychiatric } \\
\text { hospital in São Paulo/SP. }\end{array}$ & $\begin{array}{l}\text { The crack was the drug of choice in } 42.9 \% \text { of participants, followed } \\
\text { by } 30 \% \text { alcohol. The prevalence of sexual dysfunction symptoms } \\
\text { was } 34.2 \% \text {. There was an association between symptoms of sexual } \\
\text { dysfunction, low education and drug addiction. }\end{array}$ \\
\hline Pedroso et al. $(2013)^{12}$ & $\begin{array}{l}\text { Qualitative study. } \\
\text { Semi-structured interview. }\end{array}$ & $\begin{array}{l}5 \text { women and } 9 \text { men crack users, aged } 20 \\
\text { and } 30 \text {, interned to a psychiatric hospital } \\
\text { in Porto Alegre/RS. }\end{array}$ & $\begin{array}{l}\text { The study founded specificities on crack abuse by women: while } \\
\text { men are involved with the crime for the drug, women wear } \\
\text { prostitution, exposing themselves to risks. In treatment, difficulties } \\
\text { have been encountered to access the internment, relapses and } \\
\text { treatment dropout. }\end{array}$ \\
\hline Romanini e Roso $(2013)^{21}$ & $\begin{array}{l}\text { Qualitative study. } \\
\text { Participant observation, field diary and } \\
\text { focus groups. }\end{array}$ & $\begin{array}{l}16 \text { participants of both sexes, users of a } \\
\text { CAPSad, Santa Maria/RS. }\end{array}$ & $\begin{array}{l}\text { Gender stereotypes are present among crack users, where the } \\
\text { prostitution is seen as a "women's thing" and the robbery is } \\
\text { reported by men as a way to keep the drug. }\end{array}$ \\
\hline Levandowski et al. (2014) ${ }^{27}$ & $\begin{array}{l}\text { Quantitative, cross-sectional study. } \\
\text { SCID-I, ASI-6, Cocaine Selective Severity } \\
\text { Assessment and The Fagerstrom Test } \\
\text { for Nicotine Dependence. }\end{array}$ & $\begin{array}{l}\text { A total of } 48 \text { women crack users in a } \\
\text { hospital ward in southern Brazil. of } \\
\text { these, } 24 \text { with a history of childhood } \\
\text { maltreatment and } 24 \text { with no history of } \\
\text { childhood maltreatment. }\end{array}$ & $\begin{array}{l}\text { It was identified that the crack users participants with early } \\
\text { stress due to maltreatment in childhood had higher levels of } \\
\text { tumor necrosis factor (TNF) and lower levels of the weak inducer } \\
\text { of apoptosis related to TNF than crack users without early stress. } \\
\text { Also the positive relationship between TNF levels the severity of } \\
\text { symptoms of craving and severity of maltreatment of children was } \\
\text { identified. }\end{array}$ \\
\hline Pinto et al. (2014) & $\begin{array}{l}\text { Transversal quantitative study. } \\
\text { Medical records. }\end{array}$ & $\begin{array}{l}\text { The study was conducted in São } \\
\text { Paulo with a total of } 598 \text { women (the } \\
\text { participants sought treatment center } \\
\text { specializing in HIV/AIDS). }\end{array}$ & $\begin{array}{l}\text { The article shows the profile of the survey participants in which } \\
\text { most were white, single, almost half of the interviews has over } \\
8 \text { years of formal education, and 13\% reported the use of crack/ } \\
\text { cocaine. The study concludes by pointing the relationship between } \\
\text { drug use and sexually transmitted diseases such as AIDS and } \\
\text { syphilis. }\end{array}$ \\
\hline Viola et al. $(2014)^{22}$ & $\begin{array}{l}\text { Quantitative study, follow-up. } \\
\text { ASI-6, Cocaine Selective Severity } \\
\text { Assessment. }\end{array}$ & $\begin{array}{l}104 \text { women crack users, with }(C S A+) \text { and } \\
\text { without (CSA -) a history of child abuse } \\
\text { sexual, and } 20 \text { controls, } 18-55 \text { years. }\end{array}$ & $\begin{array}{l}\text { Plasma levels of GDNF in CSA group + increased during three weeks } \\
\text { of detoxification. In contrast, those in the CSA group showed lower } \\
\text { levels of GDNF and stable under the same conditions. During the } \\
\text { initial abstinence, plasma levels of GDNF and NT4/5 were the only } \\
\text { factors to show changes associated with a history of childhood } \\
\text { sexual abuse. }\end{array}$ \\
\hline
\end{tabular}

Twelve quantitative design articles and 4 qualitative design articles were found. In the quantitative studies, the instruments used to check the use of drugs were mostly structured and semi-structured interviews besides questionnaires that had the diagnostic criteria according to DSM-IV-TR ${ }^{14}$. The other utilized instruments were: Structured Clinical Interview for DSM Disorders (SCID-I), Addiction Severity Scale, Addiction Severity Index(ASI-6), Cocaine Selective Severity Assessment (CSSA), and The Fagerston's test. In the qualitative studies, it was used participant observation, open interviews and in-depth interviews.

Regarding the sociodemographic data found in the analyzed studies, the referred education background was less than eight years of formal education ${ }^{15,16}$ and in most part of the searches women entitle themselves as single. As explained in a study ${ }^{17}$, the women users of crack have as a characteristic being consumers of licit and illicit drugs before 15 to 27 years old. The profession of informal cases were of ten connected to prostitution.
Studies demonstrated that crack consumption among women has characteristics such as use intensity, prostitution, pregnancy and vulnerability. The intensity of crack use has been evidenced for more than a decade, according to the study data, when $87 \%$ of cocaine users in its various forms (inhaled smoked, injected) were men. However, those who used it in larger quantities were women ${ }^{15}$.

Prostitution is stated as a way of obtaining and maintaining crack use ${ }^{12}$, resulting in sexually transmitted diseases and $\mathrm{HIV}^{17-19}$. A study ${ }^{17}$ sought to draw a profile of 598 women that were being treated in a specialized unit of HIV/AIDS. Of these, 13\% reported the use of drugs (including crack and tobacco as the most common), $49.6 \%$ had more than eight years of formal education, $67.2 \%$ were white and most of them have a life story related to exposure to violence, abuse or neglect.

The use of crack during pregnancy also reflects the vulnerability of the crack users women, by failing to remain abstinent during this period ${ }^{20}$. Gender differences were also 
discussed in the studies. In a qualitative study, it was observed that women report prostitution as an exchange for money or drugs, as men say they do not prostitute themselves, but confess committing crimes to make money in order to keep using drugs ${ }^{12}$. Another qualitative study approaches that men refer to prostitution as only done by women ${ }^{21}$. Also emphasized that prostitution being seen as way to get crack, the majority of women reported not having used a condom during sexual intercourse $\mathrm{e}^{17,19}$.

Issues like physical neglect, sexual abuse, exposure to violence and trauma were related to drug use in women in other articles ${ }^{22-25}$. In the study of ${ }^{24}$, from the 99 women crack/ cocaine users interviewed, most state they have been victims of aggression/physical abuse and/or witnessing violence. Exposure to trauma was reported in $86.9 \%$ of cases and $15.1 \%$ of the participants closed the diagnostic criteria for post-traumatic stress disorder (PTSD). Also in relation to physical neglect in childhood, a study with a clinical group of 32 women crack users with physical neglect in childhood and 48 women with no history of physical neglect, showed that women who had higher abstinence symptoms and depression were also those who suffered physical neglect in childhood 25 .

Also regarding the presence of a history of childhood maltreatment (physical or sexual abuse), three studies found differences regarding the physiological aspects of women crack users in withdrawal symptoms, with and without history ${ }^{25-27}$. Having a history of childhood sexual abuse was associated with higher levels of glial cell line-derived neurotrophic factor (GDNF) in crack users women ${ }^{25}$. Precocious stress caused by child abuse, had modulating effect on the immune system of crack users, acting on pro-inflammatory processes ${ }^{26,27}$. Another study also investigated physiological aspects, finding higher cortisol levels in crack users women who had stressful events three months prior to treatment ${ }^{28}$.

\section{DISCUSSION}

Sociodemographic characteristics found in most studies corroborate the data from the National Profile on Use of Crack/ similar in Brazil ${ }^{7}$, revealing that these characteristics need to be considered in the treatment, where the low education, for example, can hinder communication between health professionals and the women who are in the program.

The problematic of sexually transmitted diseases, especially HIV, has also been discussed in the international literature, where crack users are considered a risk group ${ }^{29}$. There is epidemiological evidence on the association of crack use and the highest probability of HIV infection ${ }^{30}$. Other factors, such high levels of nicotine use, are associated to sexual dysfunction symptoms, according to a Brazilian study ${ }^{31}$. In a study of 8,538 drug users in the United States, crack and cocaine users were more likely to prostitution in order to obtain dru$\mathrm{gs}^{32}$. In addition, another American research with 4,861 men and women in detention because of the drug use and trafficking, found that young and low-income women were more likely to engage with the crack trade than other drugs ${ }^{33}$.

The analyzed studies address the vulnerability of the women users of crack, because they are more likely to be victims of violent acts related to sexuality than men?. In addition, the women suffer prejudice from several social groups and also among crack users ${ }^{21,34,35}$. The prejudice also makes it harder to access the health services, since there is less seeking treatment for the use of drugs compared to men ${ }^{10}$.

Other findings refer to the little knowledge of crack users expectant mothers on diseases prevention, pregnancy risk and its relation with the use of drugs ${ }^{8}$. In other study ${ }^{36}$, the pregnancy did not work as a turning point, meaning that the significant occasion of pregnancy did not contribute to stopping the drug use. The women report that the risk factors of drug use during pregnancy are: family issues, partner absence, financial instability, low self-esteem and loneliness ${ }^{8}$. It is noticed that the use of drugs by women may be underdiagnosed, because expectant mothers may predict criticism from health professionals, denying or reporting a lower consumption of drugs ${ }^{37}$.

Such findings corroborate with the data from the National Survey on the Use of crack, in which $44.5 \%$ of the women interviewed reported having been victims of sexual violence in life, compared to $7.0 \%$ reports of the same nature by men?. It was also noted that studies have been concerned to meet physiological aspects of women crack users ${ }^{25-27}$. The precautions concerning the crack users, and its social consequences, should also be understood under their biological aspects, emphasizing the biopsychosocial interaction of substance use disorders ${ }^{14}$. Besides that, being able to know physiological characteristics in relation to child abuse becomes relevant as the women crack users index with a history of violence is high ${ }^{7,9}$

These data are similar to the systematic review ${ }^{11}$, which shows the importance of programs that address the needs of the female audience with motivational interventions to reduce ambivalence, besides the trust between professionals and women users in order to increase the treatment effectiveness.

\section{CONCLUSION}

The analyzed studies show that the use of crack by women present a complex phenomenon, encompassing other issues, such as the lack of education, physical and sexual violence, risk pregnancies, sexually transmitted diseases, besides HIV and AIDS coming from the prostitution. 
The gender differences were shown, as the intensity of crack use was higher, when compared to men. In addition, the prejudice by the health professionals composes a vulnerability portrait; requiring specifically focused treatments in the women users. However, based on the Brazilian empirical studies, it is clear that there is a lack of intervention studies. It becomes essential the realization of studies to analyze the effectiveness of different treatments for women crack users.

It is noteworthy that all the researches found are related to cross-sectional data and, in most cases, quantitative studies. Quantitative analysis allow the knowledge over the studied population at the present time with problems related to the use of crack. Longitudinal studies may provide more robust data on possible influences to the start of drug use. No study relating to clinical trial interventions for this population has been identified. In this perspective, one realizes the need for research aimed at evaluating specific interventions for women crack users, so that they have effective treatments based on evidence. It is suggested that future researches address other databases also analyzing international literature about crack use in women.

\section{INDIVIDUAL CONTRIBUTIONS}

All authors contributed equally in the design of this work, as well as defining the study design, writing, discussion and final review of the text.

\section{CONFLICT OF INTEREST}

The authors report no declarations of interest.

\section{ACKNOWLEDGMENTS}

We are thankful to the Coordenação de Aperfeiçoamento de Pessoal de Nivel Superior - Capes (Brasil) for the first author's Master Degree and Doctorate Degree scholarship.

\section{REFERENCES}

1. Laranjeira R. Legalização de drogas e a saúde pública. Ciênc Saúde Coletiva. 2010;15(3):621-31.

2. United Nations Office and Drugs and Crime - UNODC. Relatório Mundial sobre Drogas. 2013; Available from: http://www.unodc.org/documents//po-brazil//Topics_drugs/ WDR/2013/PT-Referencias_BRA_Portugues.pdf.

3. O'Brian CP. Drug addiction and drug abuse. 2001; In: Hardman JD, Limbird LE, Goodman GA (ed.). Goodman \& Gilman's: pharmacological basis of therapeutics. 10 ed. New York: McGraw-Hill. p. 621-5.

4. Sakiyama HMT, Ribeiro M, Padin MFR. Prevenção da recaída e treinamento de habilidades sociais. In: Ribeiro M, Laranjeira R (Eds.). 0 tratamento do usuário de crack. São Paulo: Artmed, 2012. p. 337-50.
5. Laranjeira R (org). II Levantamento Nacional de Álcool e Drogas - LENAD. São Paulo: Instituto Nacional de Ciência e Tecnologia para as Políticas Públicas de Álcool e Outras Drogas, 2012.

6. Secretaria Nacional de Políticas sobre Drogas. Prevenção do uso de drogas: capacitação para conselheiros e lideranças comunitárias. Brasília: SENAD, 2013.

7. Fiocruz. Perfil dos usuários de crack e/ou similares no Brasil. 2013. Available from: http:// www.brasil.gov.br/cidadania-e-justica/2013/09/brasil-realiza-pesquisa-sobre-0-usodo-crack.

8. Portela GLC, Barros LM, Frota NM, Landin APP, Caetano JA, Farias FLR. Percepção da gestante sobre o consumo de drogas ilícitas na gestação. SMAD, Rev. Eletrônica Saúde Mental Álcool Drog. 2013;3(2):58-63.

9. Wolle CC, Ziberman ML. Mulheres. In: Diehl A, Cordeiro DC, Laranjeira R (Org.). Dependência Química: prevenção, tratamento e políticas públicas. Porto Alegre: Artmed. 2011. p. $375-82$.

10. Lima HP, Macedo JQ, Braga VAB, Lemos AM, Silva IAJ. Profile of women drug addicts treated at the Psychosocial Care Center Alcohol And other Drugs - documental study. Online Braz. J Nurs 2011;10(2). Available from: http://www.objnursing.uff.br/index.php/nursing/ article/view/3257.

11. Finfgeld-Connett DF, Johnson ED. Substance abuse treatment for women who are under correctional supervision in the community: a systematic review of qualitative findings. Issues Ment Health Nurs. 2011(10):640-8.

12. Pedroso RS, Kessler F, Pechansky FP. Treatment of female and male inpatient crack users: a qualitative study. Trends Psychiatry Psychother. 2013;35(1):36-45.

13. Zoltowski APC, Costa AB, Teixeira MAP, Koller SH. Qualidade metodológica das revisões sistemáticas em periódicos de psicologia brasileiros. Psicologia: Teoria e Pesquisa. 2014:30(1):97-104.

14. American Psychiatric Association. Manual Diagnóstico e Estatístico de Transtornos Mentais. DSM 5. Porto Alegre: Artmed, 2014.

15. Orsi MM, Kessler F, Pechansky F, Araújo R, Oliveira MS, Souza AC. Características do uso de cocaína em indivíduos internados em unidades de tratamento de Porto Alegre, RS. J Bras Psiquiatr. 2004;53(6):351-8.

16. Pinto VM, Tancredi MV, Buchala CM, Miranda AE. History of syphilis in women living with AIDS and associated risk factors in São Paulo, Brazil. Rev Assoc Med Bras. 2014;60(4):3428.

17. Correa, NAB, Matumoto FH, Lonardi MVC. Doenças sexualmente transmissíveis em mulheres profissionais do sexo, Umuarama, Estado do Paraná. RBAC. 2008; 40(3):209-213.

18. Malta M, Monteiro S, Lima RMJ, Bauken S, Marco A, Zuim GC, et al. HIV/AIDS risk among female sex workers who use crack in Southern Brazil. Rev Saúde Pública. 2008;42(5):831-7.

19. Nappo SA, Sanchez Z, Oliveira LG. Crack, AIDS, and women in São Paulo, Brazil. Subst Use Misuse. 2011;46:476-85.

20. Costa GM, Soibelman M, Zanchet PMC, Costa, PM, Salgado CAl. Pregnant crack addicts in a psychiatric unit. J Bras Psiquiatr. 2012;61(1):8-12.

21. Romanini M, Roso A. Midiatização da cultura, criminalização e patologização dos usuários de crack: discursos e políticas. Temas Psicol. 2013;21(2):483-97.

22. Viola TW, Tractenberg SG, Levandowski ML, Pezzi JC, Bauer ME, Teixeira AL, et al. Neurotrophic factors in women with crack cocaine dependence during early abstinence: the role of early life stress. J Psychiatry Neurosci. 2014;39(3):206-14.

23. Francke ID, Viola TW, Tractenberg SG, Grassi-0liveira R. Childhood neglect and increased withdrawal and depressive severity in crack cocaine users during early abstinence. Child Abuse Negl. 2013;37(10):883-9.

24. Tractenberg SG, Viola TW, Rosa CSO, Donati JM, Francke IA, Pezzi JC, et al. Exposição a trauma e transtorno de estresse pós-traumático em usuárias de crack. J Bras Psiquiatr. 2013;61(4):206-13.

25. Viola TW, Tractenberg SG, Pezzi JC, Kristensen CH, Grassi-0liveira R. Childhood physical neglect associated with executive functions impairments in crack cocaine-dependent women. Drug Alcohol Depend. 2013;132:271-2.

26. Levandowski ML, Viola TW, Tractenberg SG, Teixeira AL, Brietzke E, Bauer M, et al. Adipokines during early abstinence of crack cocaine in dependent women reporting childhood maltreatment. Psychiatry Res. 2013;210(2):536-40.

27. Lewandowski ML, Viola TW, Wearick-Silva LE, Wieck A, Tractenberg SG, Brietzke E, et al. J Psychiatr Res. 2014;53:180-6. 
28. Grassi-Oliveira R, Pezzi JC, Daruy-Filho L, Viola TW, Francke ID, Leite CE, et al. Hair cortisol and stressful life events retrospective assessment in crack cocaine users. Am J Drug Alcohol Abuse. 2012; 38(6):535-8

29. Figueroa JP. A comprehensive response to the HIV/AIDS epidemic in Jamaica: a review of the past 20 years. West Indian Med. 2008;57(6):562-76.

30. Cook JA. Associations between use of crack cocaine and HIV-1 disease progression: research findings and implications for mother-to-infant transmission. Life Sci. 2011;88(2122):931-9.

31. Diehl A, Silva RLS, Laranjeira R. Female sexual dysfunction in patients with substancerelated disorders. Clinics (Sao Paulo). 2013;68(2):205-12.

32. Reynolds GL, Fisher DG, Erlyana E. Crack, powdered cocaine, both or neither: a generalized logit analysis of a community-based sample. Drug Alcohol Depend. 2015;156:183-9.
33. Felson RB, Bonkiewicz L. Guns and trafficking in crack-cocaine and other drug markets. Crime Delinq. 2013;59(3):319-43.

34. Oliveira JF, Paiva MS, Valente CML. A interferência do contexto assistencial na visibilidade do consumo de drogas por mulheres. Rev Latino-Am Enfermagem. 2007;15(2).

35. Souza MRR, Oliveira JF, Nascimento ER. A saúde de mulheres e o fenômeno das drogas em revistas brasileiras. Texto Contexto Enferm. 2014;23(1):92-100

36. Marangoni SR, Oliveira MLF. Fatores desencadeantes do uso de drogas de abuso em mulheres. Texto Contexto Enfermagem. 2013;22(3):662-70.

37. Kassada DS, Marcon SS, Pagliarini MA, Rossi RM. Prevalência do uso de drogas de abuso por gestantes. Acta Paul Enferm. 2013;26(5):467-71. 